\title{
The Life Skills and Careers of Citizens in the Digital Age of Pancasila and Citizenship Education Curriculum Content
}

\author{
Farid Firdaus ${ }^{1, *}$, Aim Abdulkarim ${ }^{2}$ \\ 1,.2 Universitas Pendidikan Indonesia, Bandung, Indonesia \\ ${ }^{*}$ Corresponding author. Email: faridfirdaus13@upi.edu
}

\begin{abstract}
The article considers the rapid developments in information technology today, make all areas of life becomes all-digital, that eventually leads to a new era, which is the digital age. In this digital age, young citizens need to have life skills and careers to adapt with the competition and challenges of living in the digital age. To prepare this, education needs to include the $21^{\text {st }}$ century life skill in a curriculum. One of the $21^{\text {st }}$ century skill that need to be prepared is life skills and careers in digital age through Pancasila and Citizenship Curriculum. This study is meant to describe how Pancasila and Citizenship Curriculum prepare for life skills and careers in the current digital age as one of the competencies to have to prepare digital citizens. This study presupposes a qualitative approach with document analysis methods. Data collecting uses literature studies and document studies. The study conclusion shows in curriculum document of Civic Education 2013 that contains citizenship dimensions is citizenship knowledge, citizenship skill, and citizenship character, so civic education curriculum has a strategic position to provide insights and prepare young citizens for life skills and careers in digital age today and to participate in digital citizens that suits its current needs. Curriculum content of civic education in curriculum 2013 already contains elements of life skills and careers like flexibility and adaptability, initiative and self regulation, social and cultural interaction, productivity and accountability, compliance and responsibility.
\end{abstract}

Keywords: Citizenship Education, Curriculum, Digital Age, Life Skill and Career, Pancasila.

\section{INTRODUCTION}

The rapid changes of the $21^{\text {st }}$ century made it necessary for individual countries to prepare for the necessary quality of human resources to adapt to global and digital competition. The $21^{\text {st }}$ century was also known as the age of knowledge because all aspects of life in meeting needs, including education, referred to knowledge[1]. It is a development of the $21^{\text {st }}$ century that is so quickly characterized by the everyday use of technology, information, and communication. Using this technology, information, and communication has been supported by the presence of the internet which allows all to access the necessary information and to communicate with anyone without being penetrated by space and time. This kind of life eventually gave rise to a digital era, an era in which digital citizens could benefit from the internet in their daily lives. In addition to the highly developed information and communication technologies, in the $21^{\text {st }}$ century competition in the work world will become increasingly intense, as the work world begins to combine machines, robots and cybersystems that may begin to replace humans. So the quality of human resources in today's digital technology is essential to preparing for future life.

A study of the United Nations statistics and statistics agency shows that in 2015-2030 Indonesia will get a demographic bonus. In this period, the productive age of the Indonesian population will be quite high and the dependency rate is low, so that if it can be maximized, the Indonesian state will have abundant human resources. But, on the other hand, failure to prepare well for such an abundance of human resources can become a burden for the state, such as unemployment. Therefore it needs to equip the rising generation with your illation of knowledge, technology and life skills and careers. There are three factors why the prowess of the 21 st century was urgently needed the first economic factor, the dual citizenship, and the third of globalization factors [2]. Economic factors, by replacing human power by computers and machines, can depress costs as effectively as possible. Citizenship is an important thing to present to students, in the $21^{\text {st }}$ century students need to be given knowledge of citizenship concerning rights and 
obligations, students' involvement in government life, to be good citizens, to think critically of information, to learn to make decisions, to submit to aspirations or suggest policies and perform civic responsibilities in the best possible way. The factor of globalization is one that needs to be prepared for $21^{\text {st }}$ century students as well, for with global changes, transport, the internet, climate change, international trade and wars, it is necessary for students to learn to start communication, work together and solve problems with the citizens of the world.

In preparing human resources who are ready to compete in the $21^{\text {st }}$ century, the Indonesian state has encountered various problems. Based on the results of the 2014 ASEAN Business Outlook survey, it was stated that Indonesia is one of the destination countries for foreign investment in the ASEAN region. In addition, the results of the survey report state that the quality and ability of Indonesian workers is in low order and salaries are low. Looking at this report, Indonesia will find it hard to compete, and employment opportunities will be lost, for good job opportunities if not balanced between the quality of the workforce and scoring well-skilled graduates will be difficult to withstand the stiff competition of the $21^{\text {st }}$ century. Another result of the 2015-2016 global data produced by the world economic forum shows that Indonesia's global competitiveness index still exists under the countries of Singapore, Malaysia and Thailand. It is equally true that young citizens today tend to be selfish, the more individualistic unions and indifference, the slowdown of patience toward anarchists, the lowering of religious norms, the lowering of nationality, the disrespecting of self, the lack of self-worth because of laziness, lack of confidence in self ability, and inconsistent or unstable [3]. Entering the digital era today, Indonesian citizens, especially today's young citizens, are among the highest users of internet use and using social media as a medium to communicate and exchange information. But it still brings poor results to Indonesia because, as reported by the digital civility index (DCI) survey that saw the digital civility index (DCI) civility of Internet users in 2020, Indonesia ranks 29 of 32 countries surveyed. According to the data, Indonesia is one of the world's low levels of digital courtesy and low levels of southeast Asia at the bottom. Among the things affecting surveys regarding digital courtesy in Indonesia are the still rampant hoax and fraud, hate speech, and the absence of differences or discrimination includes bullying. A closer look at what is happening at the time of the digital age turns out the technology that should be used to support quality human life, but into a victim of technological sophistication.

The rapid change of the $21^{\text {st }}$ century certainly needs to be met with a good and needed solution to solve all the problems of Indonesia. Efforts must be made to improve the quality of Indonesian citizens to have the skills of the $21^{\text {st }}$ century so that each citizen can adapt to the existing conditions. Necessary qualifications, such as life and career proficiency, innovation and learning, and information and media process [4]. Any individual who has that ability will be able to adapt to current developments. One of the necessary qualifications is life and career skill, for this ability will be useful to everyone including students at school to prepare to adapt to today's developments. High school students as individuals who will play the role of future citizens need to be prepared for life skills and careers, as high school students will soon look to their careers in the future. This life and career skill consists of flexibility and adaptability, initiative and self-direction, social and cultural skills, productivity and accountability, leadership and responsibility. In the future a student can be successful depending on 21 st century skills, so students must continue to learn in order to have them [5].

Citizenship is part of the subject subject of $21^{\text {st }}$ century subjects and themes published in the $21^{\text {st }}$ century [6]. So citizenship competence plays a key role in the negotiations of $21^{\text {st }}$-century citizens who are ready to adapt to the future. Civics have a strategic role in preparing good and intelligent citizens. Civic knowledge, civic skills, and civic disposition [7].

Previous research studies related to this research are research conducted by (Jayadiputra at all, 2019) regarding " $21^{\text {st }}$ Century Competencies in the Citizenship Education curriculum". The result of this research is that $21^{\text {st }}$ century competencies already exist in the Citizenship Education curriculum which includes affective, cognitive and psychomotor competencies in which there is the ability to be creative, innovative, think critically, solve problems, communicate, collaborate and literacy [8]. From this research, it can be seen that $21^{\text {st }}$ century competencies need to be prepared immediately and Citizenship Education plays an important role in preparing life and career skills in digital age now.

In 2013, governments issued policies by issuing new curricula, 2013 curriculum, and throughout its travels to date, revised or improved curriculum to suit the demands of changing times that produce superior human resources. The Indonesian civics education curriculum has come to change the national curriculum. This change includes the content or education materials of citizenship itself so that its hope can improve the competence of civic education in preparing the quality of the Indonesian generation that have life and career skills that are useful for living in digital age now. As we all know that the curriculum is the heart of education which has an important role in preparing students, as well as the Pancasila and Citizenship Education curriculum which is still undergoing revisions to find the right formulation in order to adapt to current developments in preparing good citizens in the world. digital era. Initial findings in the Civics curriculum still appear to be cognitively dominant, while the aspects of attitudes and skills have not been implemented in a balanced manner, while the aspects of 
attitudes and skills should be implemented in a balanced manner and raise citizens' life and career skills in civic skills.

Referring to the above, this study aims to determine whether life and career skills in the digital era have been accommodated in the contents of the Pancasila and Citizenship Education curriculum at the high school level.

\section{THEORETICAL REVIEW}

\section{The Life-Skills and Careers Citizens of The Digital Age}

In the face of the challenges of the $21^{\text {st }}$ century full of global competition and the use of information technology and communion so rapidly, students as future citizens need to have life and career skills in order to compete and adapt to the demands of the digital age. Life skills are a chain of knowledge and expertise one must possess in order to stand alone in life [9]. Life skill enables one to be able to live life, cope with all problems and solve problems successfully. This life skill is necessary for students to prepare for life and career in digital age today.

Life skills include citizenship, life and career, and personal and social responsibilities [10]. While life and career skills according to Trilling and Phadel include flexibility and adaptability, whereby students can adjust oneself or adapt to current state of change and be flexible in learning process and activities in groups. Initiative and self-direction, which is that students manage purpose and time, work independently and become self-manage students. Social and cross-cultural interaction, in which students can effectively comunicate and cooperate with heterogen groups. Productivity and accountability, which is that students are capable of managing tasks or projects and producing products, leadership and responsibility, which is that students are capable of leading and manage their friends and accountable to everyone.

Digital citizens, those who have been using the Internet regularly in daily life [11]. Students as part of a young citizen living in the digital age are certainly familiar with the use of the internet because in everyday life the student already uses the internet through his smartphone, so the sophistication of this technology must be coupled with the life skills and careers the student needs to have so that this student will be able to adapt to technological capabilities, information and communication support to improve the quality of human resources, not vice versa. Then students as a digital citizen need to have digital skills as follows, first qualified to operate a $T I K$. The second, utilize technology as a contribution to education, culture, economics. Third developed critical thinking skills. Fourth makes use of $T I K$ as part of positive communication with others. Fifth demonstrates honest and integrity conduct [12].
Contents of The Pancasila Education and Citizenship Curriculum

The terminology of curriculum is a number of subjects the school students must walk or complete to obtain a diploma [13]. The curriculum may also mean the entire school effort in class, on page and outside of school [14]. This exposure then impvises some understanding, first, the curriculum consists not only of a number of subjects but also of all potential scientifically organized activities and experiences, second, those activities and experiences not only occur within the classroom but also the schoolyard and even outside the school. It is also then integrated into society that is so comprehensive. The 2003 rule number 20 of the year 2003 national education system states that curriculum is a set of plans and Settings on purpose, content, and materials and ways used as a guide to the learning activities arrangements for a particular educational purpose. Based on that understanding, there are two dimensions of the curriculum, the first being the plan and Settings on purpose, content, and lesson materials, while the second is the means used for learning activities. As for the components of curriculum development, that is the components of goals, the content components, the method components, and the evaluation components. These components of one another are interrelated [15].

The Indonesian citizenship education term is a translation of the civic education or integrated education or education for inequality. However, the term civics education has now turned into pancasila and civics as in the application of the 2013 curriculum.

In article 37 of law no. 20 of 2003, the national education system also explained that civic education is the name of one subject asa charge in the primary and secondary education curriculum. Under such conditions, pancasilla education and citizenship (general) are essential subjects that must exist in both basic and secondary education. The aim of the state is to develop citizenship education so that each citizen is a good citizen (to be good citizens), one who has intelligence (civics intellect) of both intellectual, emotional, social, and spiritual; Have a sense of pride and responsibility (civics vics); And was able to participate in people's lives [16]. Through civics it is expected to be able to form good, intelligent citizens, both intellectually, emotionally, socially and spiritually, which will be the basic orientation of human beings in order to participate actively in society, national and civic lives, supported by a sense of responsibility in every action in administering his rights and duties. The design of pancasila education and citizenship are basically further defined into the vision of a civics education mission. The vision of civic education in the age of globalization needs to be pointed at developing the quality of individual development, sense of individual development, and autonomous and autonomous personality [17]. The mission from a 
subjective civic education to the pedagogical is to develop learners into men who have nationalistic and patriotic feelings.

Pancasilla and citizenship education have a wide scope of content and object learning, as civics are multidisciplined. The scope of citizenship education essentially includes the four national pillars that include pancasila, the constitution of the republic of Indonesia in 1945, the united republic of Indonesia and the bhinneka single ika. It is described more specifically in PPNG materials as listed in the 2016 ministry of education and culture policy supplement on the content standards for basic and secondary education units that explain that the general space for secondary education (X-XII class), includes:

1. The dynamics of human-rights violations and their fair treatment.

2. The values and morals contained in the constitution of the republic of Indonesia 1945.

3. Spirit overcome the threat to build a national integration within a frame of Bhinneka Tunggal Ika.

4. The dynamics of national and state life are in accordance with NKRI and geopolitics Indonesia.

5. Ideal value, instrumental, and introductory Pancasila precepts.

6. Enforcement dynamics of the chapters governing the financial and judicial powers.

7. Governing dynamics and abuses of authority by government officials and their treatment (collusion, corruption, and nepotism).

8. Strategy implemented in strengthening unity with a single frame of bhinneka.

9. Governing dynamics in the nkri and federal state concepts.

\section{METHODS}

This study uses a qualitative approach with a document analysis method, a systemic procedure to review or evaluate documents both in print and in electronics [18]. Data collection has used documentation studies, is collecting documents needed as information needed in accordance with research problems, such as curriculum archives. and literature study. That is reviewing the theory related to the research topic from the relevant literature, such as from journals, books or research results. While the data analysis process begins with the process of reviewing from various sources and existing findings, which is carried out from the results of existing documents and literature, then data reduction is carried out, is the process of building theory so that it has meaning, data display, which is the process of displaying data so that it becomes relevant so that it can be interpreted, understood, and drawing conclusions, is the process of obtaining answers so that they can have comprehensive conclusions [19].

\section{FINDINGS AND DISCUSSION}

Based on the researcher's analysis, it was found that the 2013 revision of the 2016 revision of the 2016 High School Civics Education curriculum document has formulated to prepare young citizens who are ready to face various challenges in the global and digital era. According to the Partnership for $21^{\text {st }}$ Century Skills, themes that emerge in the $21^{\text {st }}$ century include global awareness, awareness as a citizen. Global awareness covers global issues in various aspects of people's lives with diverse cultures, religions and living habits. Awareness as a citizen includes skills in participating in the life of citizens, exercising rights and obligations to fight for civil rights and accommodating individual interests in the spirit of common interests. The life and career skills of $21^{\text {st }}$ century citizens in the global and digital era have been accommodated in the content and scope of competence of the $21^{\text {st }}$ century Pancasila and Citizenship Education material. Because in $21^{\text {st }}$ century citizenship education skills have emphasized solving multidimensional problems and challenges in the global and digital era. Competence flexibility and adaptability, initiative and self-regulation Interaction and social and intercultural, productivity and accountability, leadership and responsibility have become an integral part of the contents and materials of the Pancasila and Citizenship Education curriculum. Citizenship Education is present in an effort to form citizens who can think multidimensionally [20]. There are four concepts of multidimensional citizenship, namely personal, social, temporal and spatial. Citizenship in a personal context, which encourages citizens to think critically and systematically, how to solve problems cooperatively without violence and participate in supporting digital citizenship. In the social context, it requires citizens to be able to cooperate and communicate and engage with other people in various lives. In the temporal context, digital citizenship requires citizens to adapt to new understandings relating to knowledge and values with readiness to face positive and negative things as a result of globalization. Meanwhile, in the spatial context, digital citizenship needs to be strengthened by expanding the education process for understanding and cooperation between countries, so that citizens can realize that they are part of several communities, both nationally and globally.

Regarding the standard of content or scope of the material, it has been prepared based on the age level of students and includes in-depth principles, meaning that Pancasila and Citizenship Education materials are developed with the same subject matter, but the higher the grade level or level, the deeper the discussion of the material. The broad principle means that it includes the material environment of family, friends, school, community, nation and state, as well as world relations. The subject provided includes problem solving and analysis which is included in the category of critical 
thinking, namely the category of skills and analytical skills of higher order thinking. So that the competence of Pancasila and Citizenship Education which includes intelligence, intellectually, emotionally and spiritually, has the responsibility and ability to participate in the life of the nation and the state in synergy. This is in line with the objectives of the Pancasila and Citizenship Education subjects listed in the Content Standards for Elementary and Secondary Education, namely the development of the potential of students to become human beings who believe and fear God Almighty, have noble character, and have noble personality; knowledgeable, capable, critical, creative and innovative; healthy, independent, confident; tolerance, social sensitivity, democracy and responsibility; character in accordance with the values of Pancasila, the 1945 Constitution, the Unitary State of the Republic of Indonesia, Bhineka Tunggal Ika.

\section{CONCLUSION}

Pancasila and citizenship education have an important role in preparing young citizens in the $21 \mathrm{st}$ century. Citizens with competence and life skills and careers in the 21 st century could live in communities at the local, national and global levels. Life and career skills strengthened by the competence of Pancasila and Citizenship Education which consist of knowledge, skills, and citizenship attitudes are very important in preparing the quality of Indonesian human resources who can adapt in the $21^{\text {st }}$ century which is full of global and digital challenges in order to cooperate with other nations in the world without forgetting their identity as Indonesian citizens.

\section{ACKNOWLEDGMENT}

Thanks to Universitas Pendidikan Indonesia, Bandung,Universitas Negeri Manado, Manado and The Third Annual Civic Education Conference about "Civic Education in Pandemic Covid-19: Challenges and Responses" and Yayasan Taqwa Cerdas Kreatif for the support.

\section{REFERENCES}

[1] E. Y. Wijaya et al., "Transformasi Pendidikan Abad 21 Sebagai Tuntutan Pengembangan Sumber Daya Manusia di Era Global," Seminar Nasional Pendidikan. Matematika, 2016.

[2] S. Mahanal, "Peran Guru dalam Melahirkan Generasi Emas dengan Keterampilan Abad 21," Seminar Nasional Pendidikan FKIP Univ. Halu Oleo Kendari, 2014.

[3] A. A.R, "Paradigma Membangun Generasi Emas Indonesia Tahun 2045," J. Ilm. Pendidik. Pancasila dan Kewarganegaraan, vol. 2, no. 2, p. 86, 2017.
[4] C. Trilling, Bernie and Fadel, " 21 st Century Skills: Learning for Life in Our Times," 2009, doi: 978-047-055362-6.

[5] W. D. A.J Rotherdam, "21st Century Skilss: the challenges ahead. Educational Leadership," vol. 67, no. 1, pp. 16-21, 2009.

[6] Partnership for 21st Century Skill (P21), "P21 Common Core Toolkit," 2015. http://www.p21.org/our-work/resources/1005-p21common-coretoolkit.

[7] B. M.S, Belajar "Civic Education" dari Amerika (Terjemahan Syarifudin dkk). Yogyakarta: LKIS, 1999.

[8] A. A. K. \& R. Jayadiputra E., Sapriya, "21st Century Competences in Civic Education Curriculum of Indonesia," Adv. Soc. Sci. Educ. Humanit. Res., vol. 418, p. 1, 2019.

[9] S. I, "Konsep Pendidikan Berorientasi Kecakapan Hidup (Life Skill) Melalui Pendekatan Berbasis Luar (Broad Based Education)," Ditjen Dikdasmen, Jakarta, p. 32, 2002.

[10] \& E. C. P. Griffin, "Assesment and Teaching of 21 st Century skills," Springer, 2014.

[11] F. F, "Pembentukan karakter warga negara digital sebagai instrumen untuk meningkatkan partisipasi warga negara di era digital," Humanit. J. Kaji. dan Pendidik. HAM, vol. 6, no. 1, pp. 96-115.

[12] R. . K. Mosberger, C.J. Tolbert, \& Mcneal, "Digital Citizenship, The Internet, Society, and participation," The MIT Press. http://mitpress.mit.edu.

[13] A. Z, Konsep dan Model Pengembangan Kurikulum. Bandung: Remaja Rosdakarya, 2011.

[14] A. J. Saylor, J. Galen: Alexander, William M, dan Lewis, Curriculum Planning for better Teaching and learning. New York: Holt, Rinehartand Wiston, 1981.

[15] K. D, “Analisis komponen- komponen pengembangan kurikulum 2013 pada bahan uji publik kurikulum 2013," J. Pendidikan. UPI Press, 2013.

[16] Sapriya, "Perspektif Pemikiran Pakar tentang Pendidikan Kewarganegaraan dalam Pembangunan Karakter Bangsa," Acta Civ., vol. 1, no. 2, p. 204, 2008.

[17] \& D. B. U. S. Winataputra, Civic Education. Kontek, Landasan, Bahan Ajar dan Kulur Kelas. Bandung: Prodi PKn SPs UPI, 2007.

[18] B. G A, "Development Analsysis as a Qualitative Research Method, Qualitative Research," vol. 9, no. 2, pp. 33-39, 2009.

[19] \& M. Huberman, Analisis Data Kualitatif Buku Sumber tentang Metode-Metode Baru. Jakarta: Universitas Indonesia Press terjemahan oleh Tjetjep Rohendi Rohidi, 1992.

[20] \& K. S. D. Budimansyah, PKN dan Masyarakat Multikulural. Bandung: Program Studi Pendidikan Kewarganegaraan, 2008. 